Література

$$
\text { http://atbp.onaft.edu.ua/ }
$$

[1] Минский М., Персептроны [Текст] / М. Минский, С. Пейперт. - М.: Мир, 1971. - 261 с.

[2] Розенблат Ф. Принципы нейродинамики. Перцентроны и теория механизмов мозга / Ф. Розенблат. - М. : Мир, 1965. $-478 \mathrm{c}$.

[3] Rumelhart D. E. Parallel distributed processing: Explorations in the microstructure of cognition: Foundations (Parallel distributed processing) / D. E. Rumelhart, J. L. Mcclelland. - Cambrige : The MIT Press, 1987. - 7 p.

[4] Маккалок Д. Логические исчисления идей, относящихся к нервной деятельности / Д. Маккалок, У. Питтс // Автоматы - М. : ИЛ, 1956.

[5] Goseva-Popstojanova K. Using multiclass machine learning methods to classify malicious behaviors aimed at web systems / K. Goseva-Popstojanova, G. Anastasovski, R.Pantev // Software Reliability Engineering (ISSRE), 2012 IEEE 23rd International Symposium. - IEEE, 2012. - C.81-90.

[6] Schellekens C. H. Alert classification of web application attacks: using Bayesian networks to classify alerts from anomaly based intrusion detection systems / C. H. Schellekens. - Eindhoven : Technische Universiteit Eindhoven, 2013. -90 p.

[7] Joseph A. D. Machine learning methods for computer security (Dagstuhl Perspectives Workshop 12371) / A. D. Joseph [et al.] // Dagstuhl Manifestos. - Schloss Dagstuhl-Leibniz-Zentrum fuer Informatik, 2013. - T. 3. - №. 1.

\title{
INCREASING THE LEVEL OF ENVIRONMENTAL EFFICIENCY OF INDUSTRY IS THE IMPORTANT RESULT OF ITS FUNCTIONING CONTROL
}

\author{
S. A. Voinova ${ }^{1}$, D. V. Dets ${ }^{2}$ \\ ${ }^{1,2}$ Odessa National Academy of Food Technologies, Odessa, Ukraine \\ ${ }^{1}$ ORCID: 0000-0003-0203-0599 \\ E-mail: ${ }^{1}$ voinova_s@yahoo.com
}

Copyright (C) 2014 by author and the journal -Automation technological and business - processesll. This work is licensed under the Creative Commons Attribution International License (CC BY). http://creativecommons.org/licenses/by/4.0/
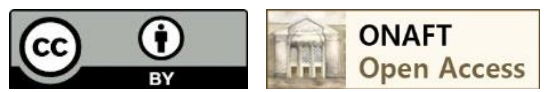

Abstract: The modern complex state of the natural environment, caused by the harmful impact of the rapidly developing world industry on it, is considered. It is pointed out the acute urgency of the utmost reduction of the harmful effects of industry. It is noted that the world's power engineering is the most active source of harmful effects increasing with acceleration on living and non-living nature. The ecological essence of the concept of energy saving is revealed. It is shown that high-quality control of the operation of technical objects is a productive means of increasing the level of ecological efficiency of enterprise operations. A chain of interrelated circumstances that determines the strict dependence of the degree of environmental friendliness of a technical object on the quality of the control process of its operation is considered. The issues of ecological modernization of the enterprise as a means of increasing the ecological efficiency of its enterprise activities are considered. There are specified the components of the company's environmental efficiency in accordance with the state standard.

Keywords: Environment, environmental friendlines, harmful impact, power engineering, energy saving, technological efficiency, ecological efficiency, functioning, technical object, control.

\section{Introduction}

World production is represented by a complex of industries that are closely interconnected by the channels of material and technical exchange and channels of energy supply - electricity and heat. The set of technical objects (TO) which included in it 


\section{http://atbp.onaft.edu.ua/}

forms a complex multi-level information pyramid, the expedient and productive functioning of which, as system, needs both in automated control system by separate parts of the pyramid and in automatic control systems (ACS) of functioning by separate TO elements. The purpose of control of the level of technological efficiency (TE) of TO operation (further, abbreviated: "TE TO" or "E $\mathrm{E}_{\mathrm{T}} \mathrm{TO}$ ") is, as is known, to maintain at a given level its components: ecological, economic and general technical efficiency.

The influence of automation facilities on the level of environmental efficiency of TO operation has particular importance.

The ecological aspect of control of properties of TO, workshops, enterprises, industries and production in general is extra importance.

In the sphere of world production, each TO used in any of its production branches interacts with its natural environment (E), in particular, with man. In this context interest is the interaction of the operating TO with E, with living and non-living nature.

As you know, any man's production activity has a harmful, destructive effect on E.

Production activity, especially intensified since the beginning of the industrialization period, caused irreparable damage to nature. This fact was recorded at an international conference in Japan, Kyoto in 1985 [1].

Statement of problem

From the middle of the last century, the ongoing development of production according to the stagnation scenario is characterized by an increase in the negative impact on the $\mathrm{E}$. This circumstance requires adequate or excessive strengthening of environmental, nature protection activities.

The state of the specific TO, its technological properties and the level of TE TO are the result of the implementation of the process of control its creation and control its using in the production process.

With a progressive approach to control of the TO operation, a set of control actions is formed from three stages [2, 3]: strategic, tactical and operational.

As a result of the implementation of this control model, they obtain a new TO with the initial, maximum TE level ( $\left.\mathrm{E}_{\mathrm{T}}\right)$. The created TO in this state is put into operation, in operation.

Created with the use of a progressive approach, the new TO has a maximum level of $\mathrm{E}_{\mathrm{T}}$, including the maximum level of its ecological component $-\mathrm{E}_{\mathrm{L}}$, economic $\mathrm{E}_{\mathrm{N}}$ and general technical component $\left(\mathrm{E}_{\mathrm{GEN}}\right)$.

In the process of TO maintenance, it undergoes a continuous negative impact of the wear process. As a consequence, the level of its $\mathrm{E}_{\mathrm{T}}$ continuously decreases.

According to the current standard, when the current level $E_{T}$ is reduced to the minimum permissible level ( $\left.E_{\min }\right)$, the object finishes spending the working capacity resource $\left(R_{S}\right)$, reaches the limit state and is subject to a complete update-replacement with a new TO.

Solutions of problem

The development of world production on the industrial scenario proceeding from the middle of the 19th to the middle of the 20th century based on achievements in the development of science and technology. However, along with, on the whole, positive results of this process, it is expanding the sharply negative process of the ever increasing harmful impact of production on the E.

For its weakening and subsequent elimination, that is, to improve the normalization of the state of E, it is necessary to find and put into operation highly productive environmental protection facilities. They, naturally, should also rely on the achievements of science and technology, on scientific and technological progress. These provisions give status to science and technology, make them the driving force of the world environmental protection activities of mankind.

Level $\mathrm{E}_{\mathrm{T}}$, including level $\mathrm{E}_{\mathrm{L}} \mathrm{TO}$ is defined by quality of process of control by its technological process. Consequently, all other things being equal, the quality of the object control process determines its environmental friendliness. That is, improving the quality of control of TO is a environmental protection tool. Giving it a targeted priority raises its status to the level of the concept. Thus, there is reason to consider the use of the process of control the TO operation as the environmental protection concept [4].

The main task of the ACS is to control the level of its environmental friendliness. The number of indicators of the current level of environmental friendliness of the TO can be more than one unit.

The level of efficiency of the process of functioning of a production object, regardless of the degree of its perfection, depends to a high degree on the quality of the control of this process.

Production objects, regardless of their industry, product and scale, are complex systems of interrelated elements. In them, the quality of the technological process reflects several indicators. In such cases, the ACS maintains several indicators at a given level. The main among them, in the general case, is to choose $\mathrm{E}_{\mathrm{L}}$. However, in a number of cases, for example, in the energy sector, in transport as the main indicator are chosen the elements $\mathrm{E}_{\mathrm{GEN}}$ reliability, safety and ergonomics of work. Such indicator of the TO state is taken as the key, a TO resource is assigned to it.

A special attention is drawn to the peculiarities of control of the TO environmentally friendly, which subject to partial renewal on the basis of modernization, reconstruction or technical re-equipment.

When they are creating a new TO or updating worn out TO, it is necessary to ensure such a ratio of its resource components, ecological $\mathrm{R}_{\mathrm{SL}}$, economic $\mathrm{R}_{\mathrm{SN}}$ and general technical $\mathrm{R}_{\mathrm{SGEN}}$, at which $\mathrm{R}_{\mathrm{SL}}$ is superior to others. In this case, the $\mathrm{TO}$, which has spent its resource $\left(\mathrm{R}_{\mathrm{SN}}\right.$ or $\left.\mathrm{R}_{\mathrm{SGEN}}\right)$, will still have a residual resource $\mathrm{R}_{\mathrm{SL}}$, that is, it will be still admissible dangerous for the $\mathrm{E}$, which corresponds to the environmental protection concept.

The closing of the TE TO balance discloses the features of the TO properties and conditions of control of the formation its $\mathrm{TE}$, in particular, the formation of its $\mathrm{E}_{\mathrm{L}}$ of operation [5]. 
To closing the TE balance it is necessary to have information about the dynamics of of changes in the level of the components of $\mathrm{E}_{\mathrm{L}}$ under the influence of $\mathrm{TO}$ wear. To expand this possibility it is necessary to develop technical gerontology [6].

If it is necessary, it should be to monitor and control the current level of several indicators - the components of the $\mathrm{E}_{\mathrm{L}} \mathrm{TO}$.

Control of the formation of the $\mathrm{E}_{\mathrm{L}} \mathrm{TO}$, the control of the current level of its indicators at all stages should have a systemic character [7].

A bright example of an industry that has a strong influence on the $\mathrm{E}$ is power engineering. As you know, power engineering is a branch of industry, which has the strongest harmful impact on the E. This is typical for both power engineering on organic fuels, its stationary and transport parts, and power engineering on nuclear fuel. The harmful effect of power engineering on the $\mathrm{E}$ is accelerating. This gives to the problem of nature saving from the impact of power engineering a critically important and urgent character. Therefore, the realized now program of energy saving has acquired especially high level of importance and complexity [8].

But its meaning and content are not understood by everyone. Even among experts in the field of technology there is an opinion that energy conservation aims to increase the duration of the period of spending by mankind of the reserves of nonrenewable sources of energy - fossil fuel, its reserves in the Earth interior. The fallacy of this opinion is obvious.

The true goal of the concept of energy saving is to strive to comprehensively and in every possible way reduce the specific (per unit of production output) consumption of energy, produced, transported and consumed in industry, that is, to reduce the specific energy consumption in industry and, as a result, to reduce the total fuel consumption.

Received in this way the target result - the reduction of the amount of burned fuel - reduces the intensity of the harmful impact of energy on the $\mathrm{E}$, that is, it causes a positive environmental effect.

At the same time, it should be taken into account that the specific fuel consumption can be reduced only on the basis of increasing the level of the $\mathrm{E}_{\mathrm{T}} \mathrm{TO}$ of power engineering. And this most important effect can be ensured only on the basis of ensuring high-quality control of the functioning of power engineering, that is, controlling the actions of its elements: generating, transporting and consuming energy.

It should be noted that the important fact is that, both in general, and in detail, the solution of the problems of energy conservation and, consequently, the tasks of high-quality control of the heat-generating TO is the more difficult the lower its unit thermal rating.

Let's note, perspective non-traditional sources of energy, similarly to traditional sources, require wide automation of control of technological process of operation. The main direction of alternative power engineeging is the search and use of nontraditional energy sources. An alternative energy source is a renewable resource. It replaces traditional energy sources, which are fossil fuels - solid, liquid, gaseous. It during combustion releases into the atmosphere heat, harmful gases that contribute to the development of the greenhouse effect, adversely affects on the living nature. The reason for searching for alternative energy sources is the need to get it from the energy of renewable or almost inexhaustible natural resources and phenomena. Alternative sources can be wind, sun, water, land, biofuel.

The above chain of interrelated provisions leads to a fundamentally important conclusion:

High-quality control of the process of functioning of energy production can ensure a high level of environmental efficiency of this process.

This important conclusion is obtained for the most complex, bright and most large-scale (in terms of the degree of harmful impact on the E) industry - power engineering. However, in others branches of modern world production, this conclusion is as true as it is important.

Thus, the high quality of control of the functioning of the TO in its specific application conditions causes an increase in the level of environmental friendliness of this object, especially as compared with its use without the ACS, that is, with the manual control of its operation. This effect is the main result of the automatic control of the operation of TO and industry in general (taking into account the problem of saving the $\mathrm{E}$ from the harmful effects of industry on its).

Currently, for energy companies, one of the most important areas of economic activity is the bringing in investments for the implementation of environmental modernization of production. In this regard, there is a need to confirm the environmental efficiency of production activities.

The environmental efficiency of an enterprise is the conformity of the production activity to objectively measurable standards of environmental impacts. According to the standard, the environmental efficiency of an enterprise means the results of managing the environmental aspects of the activity, and they can be measured in relation to the organization's policy, its goals and objectives in the field of environmental protection. Estimation of environmental efficiency is a continuous internal process of data collection and evaluation, as well as information to provide a current assessment of environmental performance and trends over time. This process allows you to determine the environmental aspects of the enterprise; To assess which aspects are most significant for changing business conditions; Set criteria for environmental efficiency; To assess the compliance of the enterprise's activities, including the control to these criteria.

The environmental aspect of the problem of the TE TO control, considered in relation to the energy sector, shows its importance in relation to industry as a whole.

\section{Conclusions}

1. The present state of the environment requires immediate adopting of extraordinary measures to decisively reduce the intensity of harmful effects on it from the industry side;

2. Control of the operation of the TO is a productive tool which determines the degree of its harmful impact on the E. Increasing the quality of TO control it can be reduced the degree of this impact; 


\section{http://atbp.onaft.edu.ua/}

3. It should be recognized that in the current world industry conditions, the main task of the ACS of the operation of any $\mathrm{TO}$ is to maintain level the its $\mathrm{E}_{\mathrm{L}}$ in a given range of values;

4. The result of control over the current level of $\mathrm{E}_{\mathrm{L}}$ of functioning of the TO should be the main indicator of the current level of TE of its operation;

5. If necessary, you should monitor and control the current level of indicators - the components of the $\mathrm{E}_{\mathrm{L}}$ of object;

6. In modern industry, there is a situation which forces to use the direct control of the level of $\mathrm{E}_{\mathrm{L}}$ of majority $\mathrm{TO}$;

7. When assigning $\mathrm{R}_{\mathrm{S}} \mathrm{TO}$, it is necessary to ensure such a ratio of its components, at which the largest is the ecological component;

8. Currently, for energy companies, one of the most important areas of economic activity is the bringing in investments for the implementation of environmental modernization of production.

\section{References}

[1] M. Grabb, et. al., Kiotskiy protokol: analiz i interpretatsiya. Per. s angl. M: Nauka, 2001;

[2] S. Voinova, "Mozhlivosti upravlinnya efektivnistyu tehnichnih ob'ektyiv," in Trudy 15-y Mezhdunar. n.-t. konf. Fizicheskie i kompyuternyie tehnologii, pp. 393-395, December 2009;

[3] S. Voinova, "O podhode k upravleniyu tehnologicheskoy effektivnostyu sozdavaemyih tehnicheskih ob'ektov," Automation of technological and business-processes, no. 11, 12, pp. 26-28, September-December 2012;

[4] S. Voinova, "Pro aktualnist upravlinnya ekologichnoyu efektivnistyu tehnichnih ob'ektiv," Energetika ta elektrifikatsiya, no. 1, pp. 64-67, 2012.

[5] S. Voinova, "Balans tehnologicheskoy effektivnosti funktsionirovaniya tehnicheskih ob'ektov v realnyih proizvodstvennyih usloviyah," Energetika ta elektrifikatsiya, no. 8, pp. 35-41, 2015;

[6] S. Voinova, "Sistemniy pidhid do upravlinnya tehnologichnoyu efektivnistyu tehnichnih ob'ektiv / Fizicheskie i kompyuternyie tehnologii," in Trudy 17-y Mezhdunarodnoy nauchno-tehnicheskoy konferentsii, pp. 105-108, September, 2011;

[7] S. Voinova, "Tehnicheskaya gerontologiya. Potentsial vliyaniya na effektivnost funktsionirovaniya tehnicheskih ob'ektov," in Tehnologii. Fizicheska kultura i sport: Mater. za VI Mezhdunarodna nauchna praktichna konferentsiya Naynovite postizheniya na evropeyskata nauka-2010, 17 - 25 yuni, 2010g. Tom 20, 2010. - S. 79-84.

[8] V. Zhovtyanskiy, "Problemy rozvitku energozbrezhennya v Ukrayini ta shlyahi yih virishennya" in Zbirnik materialiv III Mizhnarodnoyi naukovo-praktichnoyi konferentsiyi, pp. 24-34, 2001.

Литература

[1] Грабб М. Киотский протокол: анализ и интерпретация / М. Грабб, К. Вролик, Д. Брэк ; пер. с англ. - М., Наука, 2001, 303 c.

[2] Воінова С.О. Можливості управління ефективністю технічних об'єктів / С.О. Воінова // Физические и компьютерные технологии: материалы 15-й Междунар. н.-т. конф., 2-3 декабря 2009 г., Харьков, Украина / ХНПК «ФЭД». - Харьков, 2009. - С. 93-95.

[3] Воинова С.А. О подходе к управлению технологической эффективностью создаваемых технических объектов / С.А. Воинова // Автоматизація технологічних і бізнес-процесів : міжн. наук.-вир. журн. / Одеська нац. акад. харч. техн. - Одеса, 2012. - № 11, 12. - С. 26-28.

[4] Воінова С.О. Про актуальність управління екологічною ефективністю технічних об'єктів / «Енергетика та електрифікація», 2012, №1. - С. 64-67.

[5] Воинова С.А. Баланс технологической эффективности функционирования технических объектов в реальных производственных условиях / Енергетика та електрифікація, 2015, №. 8. - С. 35-41.

[6] Воінова С.О. Системний підхід до управління технологічною ефективністю технічних об'єктів / Физические и компьютерные технологии.- Труды 17-й Международной научно-технической конференции, 20-21 сентября 2011г.- Харьков: ХНПК «ФЭД», 2011. - С.105-108.

[7] Воинова С.А. Техническая геронтология. Потенциал влияния на эффективность функционирования технических объектов / Матер. за VI Международна научна практична конференция «Найновите постижения на европейската наука-2010», 17 - 25 юни, 2010г. Том 20 «Технологии. Физическа култура и спорт». - София: «Бял ГРАД-БГ» ООД, 2010. - С. 79-84.

[8] Жовтянський В.А. Проблеми розвитку енергозбереження в Україні та шляхи їх вирішення // Збірник матеріалів III Міжнародної науково-практичної конференції “Проблеми економії енергії”, Львів, 10-14 жовтня 2001р.Львів: Видавництво Національного університету "Львівська політехніка", 2001 - С. 24-34. 